\title{
KAJIAN SIMULASI PENDUGAAN SELANG KEPERCAYAAN BOOTSTRAP BAGI ARAH MEDIAN DATA SIRKULAR ${ }^{*}$
}

\author{
Cici Suhaeni ${ }^{1}$, I Made Sumertajaya ${ }^{2}$, dan Anik Djuraidah ${ }^{3}$ \\ 1Department of Statistics, Bogor Agricultural University (IPB), Indonesia, cici_suhaeni@apps.ipb.ac.id \\ ${ }^{2}$ Department of Statistics, Bogor Agricultural University (IPB), Indonesia, imsjaya@ipb.ac.id \\ 32Department of Statistics, Bogor Agricultural University (IPB), Indonesia, anikdjuraidah@ipb.ac.id
}

\section{Indonesian Journal of Statistics and Its Applications (eISSN:2599-0802) Vol 2 No 1 (2018), 35 - 45}

Copyright (๑ 2018 Cici Suhaeni, I Made Sumertajaya, and Anik Djuraidah. This is an open-access article distributed under the Creative Commons Attribution License, which permits unrestricted use, distribution, and reproduction in any medium, provided the original work is properly cited.

\begin{abstract}
The median direction is one of central tendency of circular data. The estimation process usually requires information about sampling distribution of statistic that want to be used as a parameter estimate. Theoretically, sampling distribution derived from population distribution. But, it is not easy to get sampling distribution of median although the population distribution is known. When the sampling distribution cannot be derived easily from population distribution, the bootstrap method can be an alternative to handle it. This study wants to evaluate the effect of increasing concentration parameter to the performance of bootstrap confidence interval estimation for median direction through simulation study. Three methods were used to estimate the interval which are equaltailed arc (ETA), symmetric arc (SYMA), and likelihood-based arc (LBA). The most important criterion to evaluate them were true coverage and interval width. The simulation results that in general, the increasing of concentration parameter followed by more narrow interval. For small concentration parameter $(\kappa<1)$, all methods give unstable true coverage and interval width. The authors also identify that those three methods produce intervals with identical width when the parameter concentration is 20 or more. In terms of coverage and interval width, the best method was ETA.
\end{abstract}

Keywords: Bootstrap confidence interval, Circular data, Circular statistics, Median direction.

\section{Pendahuluan}

Data sirkular merupakan salah satu jenis data berarah (directional data) yang banyak dijumpai dalam berbagai bidang. Data jenis ini secara umum dapat diukur menggunakan dua instrumen pengukuran yaitu kompas dan jam. Hasil pengukuran menggunakan kompas adalah data bersatuan arah (derajat/radian), sedangkan hasil pengukuran menggunakan jam adalah waktu, dalam hal ini dapat berupa jam/hari/bulan (Mardia \& Jupp 2000). Data sirkular diperoleh dari fenomena periodik yang berbentuk siklus, artinya nilai data yang mungkin terjadi bergerak dari nilai minimum $0^{\circ}$ dan seterusnya hingga akhirnya kembali lagi ke titik tersebut. Data seperti

\footnotetext{
${ }^{\star}$ Received Jan 2018; Accepted Apr 2018; Published online on Apr 2018
} 
ini direpresentasikan dalam bentuk lingkaran.

Data berarah terbagi menjadi dua, yaitu data bola (sperichal data) dan data sirkular (circular data). Data sirkular adalah data berarah dalam ruang dimensi dua, sedangkan data bola merupakan data berarah pada ruang dimensi tiga. Sedangkan, data yang selama ini lazim ditemui dalam kehidupan sehari-hari misalnya umur, pendapatan, jumlah penduduk, dan sejenisnya, dikenal dengan istilah data linier. Dilihat dari posisinya, data linier berada dalam ruang dimensi satu yaitu dapat direpresentasikan menggunakan garis bilangan. Nilai yang mungkin terjadi dari data ini tidak terbatas. Perbedaan sifat antara data linier dan data sirkular ini mengakibatkan perbedaan dalam prosedur analisisnya. Metode analisis yang banyak berkembang saat ini adalah analisis untuk data linier, sementara analisis untuk data sirkular masih sangat terbatas. Oleh karena itu, perlu dilakukan pengembangan metode analisis untuk data sirkular.

Salah satu ukuran pemusatan data yang sering menjadi perhatian selain rata-rata adalah median, yaitu nilai tengah setelah data diurutkan. Dalam statistika sirkular, median disebut dengan arah median (median direction).

Pendugaan selang kepercayaan baik pada data linier maupun sirkular membutuhkan informasi mengenai sebaran penarikan contoh. Secara teoritis, sebaran penarikan contoh dapat diperoleh dari sebaran populasi. Namun, tidak semua statistik memiliki sebaran penarikan contoh, seperti halnya median. Walaupun sebaran populasinya diketahui, sebaran penarikan contoh dari median ini tidak diketahui. Sehingga, selang kepercayaan bagi median tidak dapat diformulasikan secara baku menggunakan sebaran penarikan contoh. Oleh karena itu, diperlukan metode pendugaan selang kepercayaan yang tidak memerlukan sebaran penarikan contoh, yaitu dengan resampling bootstrap. Hal ini sesuai dengan pendapat Rice (2006) bahwa solusi untuk mengatasi pendugaan selang kepercayaan apabila sebaran penarikan contohnya tidak diketahui maka dapat digunakan metode bootstrap.

Selang kepercayaan dapat dievaluasi melalui dua ukuran yaitu lebar selang dan seberapa besar peluang selang tersebut dapat mencakup nilai parameter sesungguhnya (Casella \& Berger 2002). Lebar selang sangat dipengaruhi oleh keragaman data. Pada data sirkular yang memiliki sebaran von Mises (normal sirkular), keragaman data dapat dilihat dari besarnya parameter konsentrasi $(\kappa)$. Sehingga, perlu dilakukan kajian mengenai perubahan lebar selang kepercayaan data sirkular akibat perubahan parameter konsentrasi.

Pendugaan selang kepercayaan bootstrap untuk data sirkular telah dilakukan oleh para peneliti terdahulu. Ducharme et al. (1985) mengkaji selang kepercayaan bootstrap bagi ukuran pemusatan data sirkular menggunakan metode busur simetri. Fisher \& Hall (1989) memperkenalkan metode pendugaan selang kepercayaan bootstrap berdasarkan besaran pivot, yaitu metode busur ekor sama (BES), metode busur simetri (BSIM), dan metode busur berbasis kemungkinan (BBK).

Selanjutnya, Otieno (2002) membandingkan ketiga metode tersebut untuk menduga selang kepercayaan ukuran pemusatan data sirkular dengan menggunakan parameter konsentrasi $\kappa=2$ dan $\kappa=10$ dengan ukuran contoh $N=10$. Kesimpulan yang diperolehnya adalah bahwa metode selang kepercayaan yang berbeda-beda akan cenderung memberikan hasil yang sama atau konvergen dengan meningkatnya parameter konsentrasi. Kesimpulan tersebut berlaku bagi arah-rata-rata dan arah median. 
Kemudian, Suhaeni et al. (2012) membuktikan kesimpulan tersebut untuk dugaan selang kepercayaan bootstrap bagi arah rata-rata menggunakan parameter konsentrasi dan ukuran contoh yang lebih bervariasi. Hasil yang diperoleh pun memberikan kesimpulan yang sejalan dengan penelitian Otieno, yaitu metode BES, BSIM, dan BBK cenderung memberikan selang yang sempit dan konvergen seiring dengan meningkatnya parameter konsentrasi. Hasil penelitian tersebut menjadi dasar pemikiran untuk meneliti lebih lanjut mengenai pendugaan selang kepercayaan bootstrap menggunakan BES, BSIM, dan BBK bagi arah median.

Berdasarkan latar belakang tersebut, maka penelitian ini bertujuan mengkaji pengaruh parameter konsentrasi $(\kappa)$ terhadap dugaan selang kepercayaan bootstrap bagi arah median pada metode busur ekor sama, busur simetri, dan busur berbasis kemungkinan.

\section{Metodologi}

\subsection{Bahan dan Data}

Data yang digunakan dalam penelitian ini adalah data simulasi. Simulasi dilakukan dengan membangkitkan data dari sebaran von Mises dengan nilai parameter konsentrasi $\kappa=0.05,0.5,1,1.5,5,10,20,50,100$, ukuran contoh $\mathrm{N}=10,30,50$, 100 , dan arah rata-rata $0^{\circ}$. Pembangkitan data ini diulang sebanyak $M=100$ kali menggunakan software $\mathrm{R}$.

\subsection{Metode Analisis}

Langkah-langkah analisis data yang dilakukan berkaitan dengan tujuan penelitian terbagi menjadi tiga tahap. Tahap-tahap ini merujuk pada (Suhaeni et al, 2012), yaitu: Tahap I : Membangkitkan data sebanyak 100 contoh, disebut data asli.

Tahap II : Menentukan selang kepercayaan bootstrap.

Selang kepercayaan yang akan dibentuk menggunakan $\alpha=0,05$ dan dilakukan pada 100 contoh dari data simulasi. Adapun langkah-langkah dalam menentukan selang kepercayaannnya adalah sebagai berikut :

1. Mengambil contoh (sampling) dari data asli

2. Menghitung dugaan arah median $\left(\tilde{\theta}^{*}\right)$

3. Pengambilan contoh ulang (resampling) dari contoh yang terambil

Ulangi langkah 1 dan 2 sebanyak $B=500$ kali untuk memperoleh dugaan arah median $\tilde{\theta}_{1}^{*}, \ldots, \tilde{\theta}_{B}^{*}$.

4. Menentukan selang kepercayaan bootstrap.

Selang kepercayaan bootstrap bagi arah median, ditentukan dengan tiga metode (Otieno 2002), yaitu :

a. Metode busur ekor sama, dengan prosedur sebagai berikut.

1) Menghitung perbedaan ukuran pemusatan (arah median) dari data asli $(\hat{\theta})$ dan contoh bootstrap ke-b $\left(\tilde{\theta}_{b}^{*}\right)$, dengan rumus :

$$
\begin{gathered}
\gamma_{b=} \tilde{\theta}_{b}^{*}-\hat{\theta}, \\
\left(-\pi \leq \gamma_{b} \leq \pi\right) \mathrm{dan} \\
b=1, \ldots, B .
\end{gathered}
$$

2) Urutkan nilai-nilai $\gamma_{b}$ dari yang terkecil sampai yang terbesar.

$$
\gamma_{1} \leq \gamma_{2} \leq \cdots . \leq \gamma_{B}
$$


3) Selang kepercayaan busur ekor sama :

dengan :

$$
\left[\hat{\theta}+\gamma_{(l+1)}, \hat{\theta}+\gamma_{(m)}\right]
$$

$l=$ bilangan bulat terbesar $\leq\left(\frac{1}{2} B \alpha+\frac{1}{2}\right)$

$$
\begin{gathered}
m=B-l \\
\gamma_{(l+1)}=\text { nilai } \gamma \text { pada posisi } \\
\text { ke }-(l+1)
\end{gathered}
$$

b. Metode busur simetri, dengan prosedur sebagai berikut.

1) Menghitung perbedaan ukuran pemusatan dari data asli $(\hat{\theta})$ dan contoh bootstrap ke-b $\left(\tilde{\theta}_{b}^{*}\right)$, dengan rumus :

$$
\begin{gathered}
\Psi_{b}=\left|\tilde{\theta}_{b}^{*}-\hat{\theta}\right|, \\
\left(-\pi \leq \Psi_{b} \leq \pi\right), \\
b=1, \ldots, B
\end{gathered}
$$

2) Urutkan $\Psi_{b}$ dari yang terkecil sampai yang terbesar

$$
\Psi_{1} \leq \Psi_{2} \leq \cdots . \leq \Psi_{B}
$$

3) Selang kepercayaan busur simetri adalah :

dengan :

$$
\left[\hat{\theta}-\Psi_{m}, \hat{\theta}+\Psi_{m}\right]
$$

$\Psi_{m}=$ nilai $\Psi$ pada posisi ke-m.

$$
\begin{aligned}
& l=B \alpha+\frac{1}{2} \\
& m=B-\tau
\end{aligned}
$$

c. Metode Busur Berbasis Kemungkinan

Prosedur metode ini sangat fleksibel, yaitu dengan cara memilih busur terpendek yang mengandung $(1-\alpha) B$ dari nilai-nilai $\tilde{\theta}_{b}^{*}$.

Tahap III : Mengevaluasi hasil selang dugaan bootstrap.

Evaluasi selang kepercayaan didasarkan pada tiga ukuran, yaitu :

a. Cakupan sebenarnya (true coverage), yaitu persentase dari jumlah selang kepercayaan yang dengan benar mencakup arah median sesungguhnya. Cakupan yang terbaik adalah cakupan yang mendekati atau sama dengan cakupan nominal (tingkat kepercayaan).

b. Lebar selang, yang merupakan rata-rata lebar selang dari 100 simulasi. Selang yang terbaik adalah selang terpendek.

c. Keragaman lebar selang, yang diukur menggunakan ragam sirkular dari 100 lebar selang hasil simulasi. Semakin kecil nilai dari keragaman lebar selang ini, maka lebar selang yang dihasilkan semakin seragam atau konsisten.

Proses evaluasi ini ada dua tahap, yaitu :

1. Melihat pengaruh perubahan nilai $\kappa$ terhadap cakupan dan lebar selang.

2. Membandingkan selang kepercayaan bootstrap dari ketiga metode yang digunakan pada Tahap II.

Prosedur pembandingannya adalah dengan cara memberikan peringkat terhadap ketiga metode pada masing-masing ukuran contoh. Peringkat tertinggi diberi nilai 3 , tertinggi kedua diberi nilai 2 , dan terendah diberi nilai 1 . Kemudian, dihitung rata-rata peringkat dari empat ukuran contoh yang digunakan dalam simulasi ini. Metode yang menempati peringkat tertinggi pada interval $\kappa$ tertentu dikatakan metode terbaik.

3. Menarik kesimpulan. 


\section{Hasil dan Pembahasan}

Hasil pendugaan selang kepercayaan bootstrap bagi arah median untuk metode busur ekor sama, busur simetri, dan busur berbasis kemungkinan serta evaluasi dari ketiga metode adalah sebagai berikut.

\section{a. Busur Ekor Sama (BES)}

Selang kepercayaan busur ekor sama bagi arah median (BES Median) memberikan cakupan selang yang stabil saat parameter konsentrasinya sudah di atas 1,5 (Gambar 1). Hal ini berlaku untuk semua ukuran contoh. Untuk ukuran contoh $\mathrm{N}=50$ dan $\mathrm{N}=100$, cakupan mulai berada di sekitar $95 \%$ pada $\mathrm{K}=0.5$, sedangkan untuk ukuran contoh yang lebih kecil, cakupan sebenarnya masih jauh dari 95\%. Jika dibandingkan dengan cakupan selang pada ukuran contoh yang lain, ukuran contoh yang kecil cenderung menghasilkan cakupan yang lebih kecil dari yang lainnya. Hal ini mengindikasikan bahwa, data yang menyebar di sekeliling lingkaran akan membuat selang kepercayaan BES Median tidak mampu mencakup arah median sesungguhnya dengan baik.

Lebar selang kepercayaan BES Median (Gambar 2) memperlihatkan bahwa, dari empat macam ukuran contoh, lebar selang akan membentuk pola menurun (konvergen) seiring peningkatan parameter konsentrasi. Konvergensi ini dicapai saat $\mathrm{K}=20$. Ukuran contoh kecil pun menghasilkan selang yang lebih lebar dari yang lainnya. Hasil ini juga menunjukkan bahwa, selang kepercayaan BES Median akan menjadi lebar saat datanya menyebar di sekeliling lingkaran.

Keragaman lebar selang dari selang kepercayaan median menghasilkan pola yang relatif sama dengan pola lebar selang BES Median ini. (Gambar 3). Semakin besar parameter konsentrasi, keragaman lebar selang akan semakin kecil (Gambar 3). $\mathrm{k}=5$ juga menjadi titik konvergensi dari keragaman lebar selang. Artinya, ketika parameter konsentrasinya sudah lebih dari 5, maka berapapun ukuran contohnya, lebar selang yang dihasilkan dari 1000 simulasi akan cenderung seragam atau konsisten.

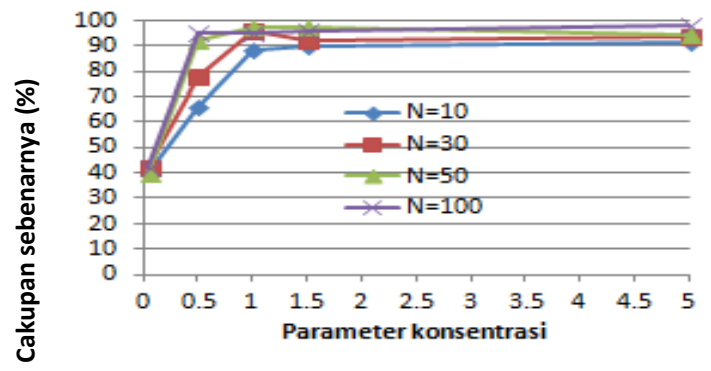

(a)k $=0.05$ s.d 5

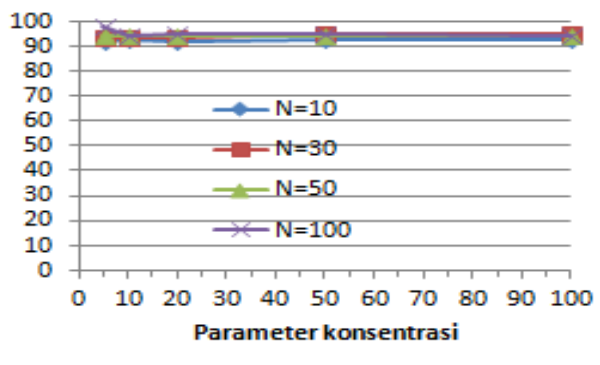

(b) $k=5$ s.d 100

Gambar 1. Cakupan selang kepercayaan BES Median 


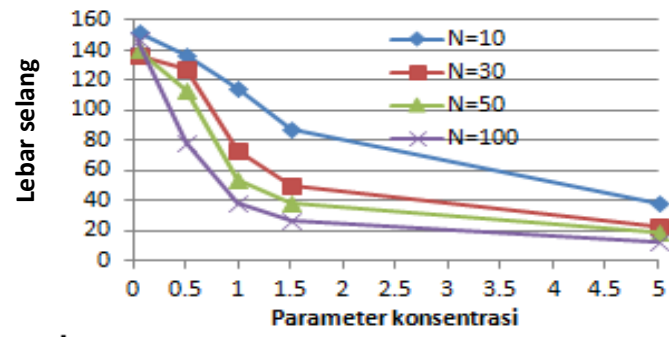

(a) $k=0.05$ s.d 5

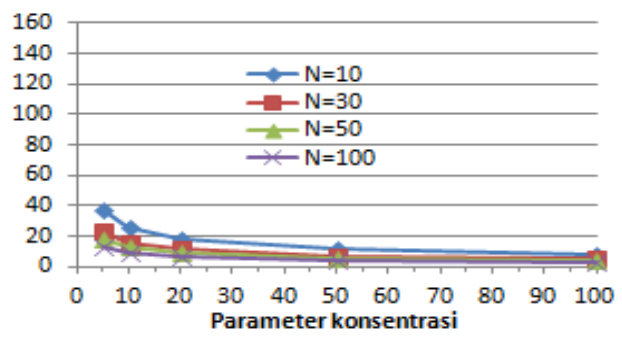

(b) $k=5$ s.d 100

Gambar 2. Lebar selang kepercayaan BES Median

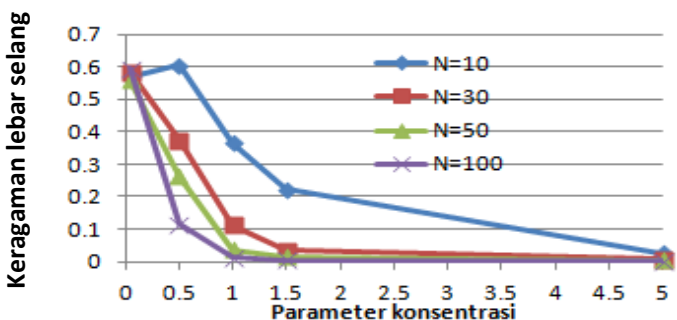

(a) $\mathrm{K}=0.05$ s.d 5

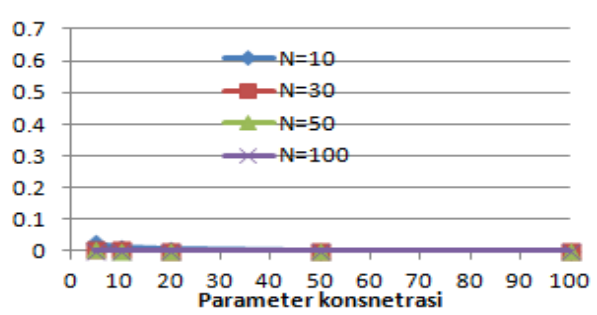

(b) $k=5$ s.d 100

Gambar 3. Keragaman lebar selang BES Median

\section{b. Busur Simetri (BSIM)}

Secara umum, hasil dari selang kepercayaan BSIMsama dengan BES. Pada $\mathrm{k}=0.05$, cakupan selang yang dihasilkan juga rendah dan jauh dari tingkat kepercayaan selang. Cakupan selang akan mulai stabil mendekati tingkat kepercayaan selang saat $\mathrm{k} \geq 1$ (Gambar 4).

Lebar selang juga menunjukkan pola yang sama dengan BES (Gambar 5). Semakin besar parameter konsentrasi maka lebar selang kepercayaan BSIM akan semakin sempit. Lebar selang dari keempat ukuran contoh akan mulai sama saat $\mathrm{k}=20$. Untuk $\mathrm{N}=10$, keragaman lebar selang pada $\mathrm{k}=0.05$ lebih kecil daripada $\mathrm{k}=0.5$. Setelah $\mathrm{k} \geq 0.5$, keragaman lebar selang semakin menurun seiring dengan meningkatnya parameter konsentrasi. Dari keempat ukuran contoh, keragaman lebar selang cenderung sama saat $\mathrm{k}=5$ (Gambar 6 ).

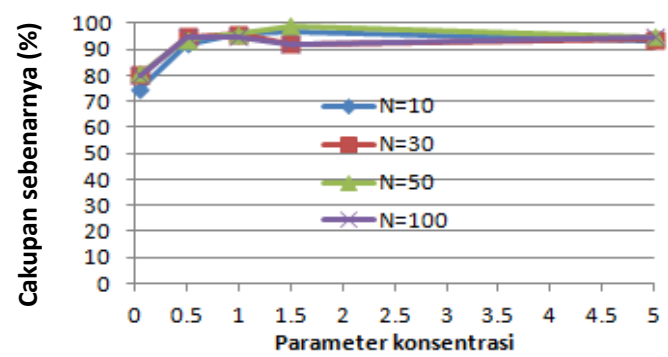

(a) $\mathrm{k}=0.05$ s.d 5

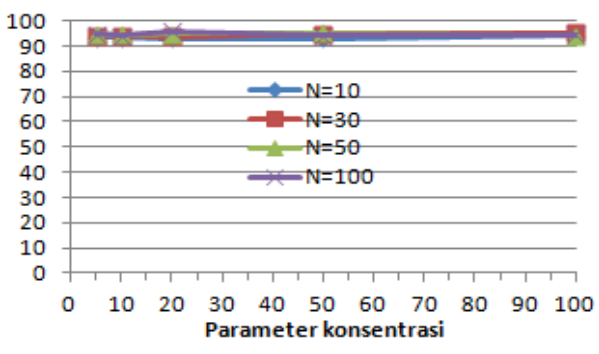

(b) $K=5$ s.d 100

Gambar 4. Cakupan selang kepercayaan BSIM Median 


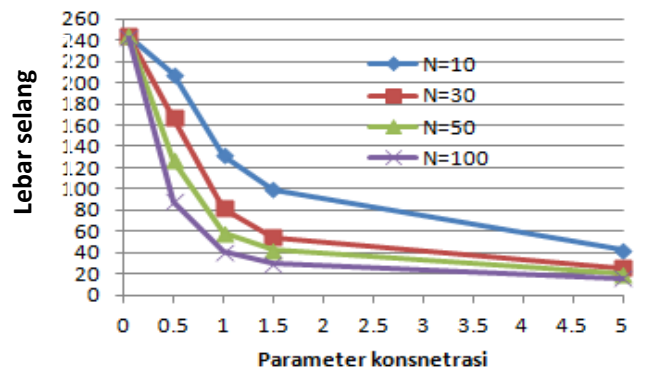

(a) $\mathrm{k}=0.05$ s.d 5

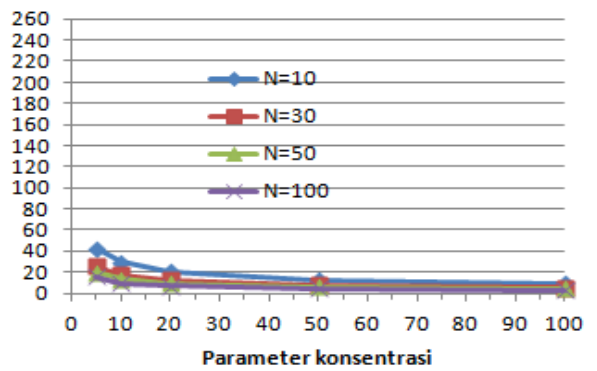

(b) $k=5$ s.d 100

Gambar 5. Lebar selang kepercayaan BSIM Median

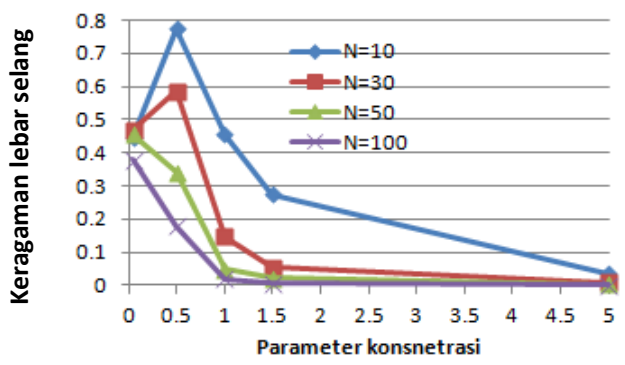

(a) $\mathrm{k}=0.05$ s.d 5

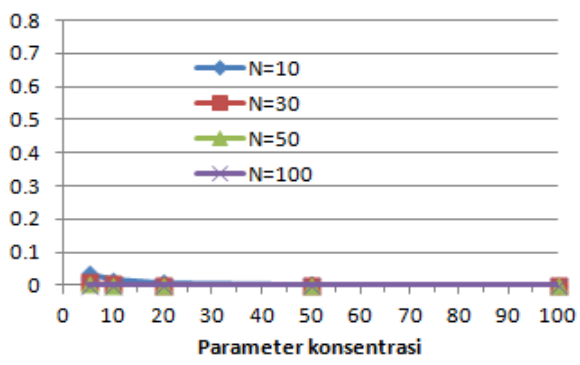

(b) $k=5$ s.d 100

Gambar 6. Keragaman lebar selang BSIM Median

\section{c. Busur Berbasis Kemungkinan (BBK)}

Hasil selang kepercayaan BBK serupa dengan BSIM. Cakupan selang jauh dari 95\% saat $\mathrm{k}<1$, setelah $\mathrm{k} \geq 1$ cakupan selang mulai stabil mendekati 95\% (Gambar 7 ). Lebar selang juga akan semakin sempit seiring dengan meningkatnya parameter konsentrasi. Pada k=20, keempat ukuran contoh memberikan lebar selang yang cenderung sama (Gambar 8).

Keragaman lebar selang BBK memiliki perilaku yang sama dengan selang BSIM. Keragaman lebar selang saat $\mathrm{k}=0.05$ lebih kecil dari pada saat $\mathrm{k}=0.5$. Setelah itu, keragaman akan terus menurun seiring dengan meningkatnya $\mathrm{k}$. Pada $\mathrm{k}=5$, keempat macam ukuran contoh sudah memberikan hasil yang cenderung sama (Gambar 9).
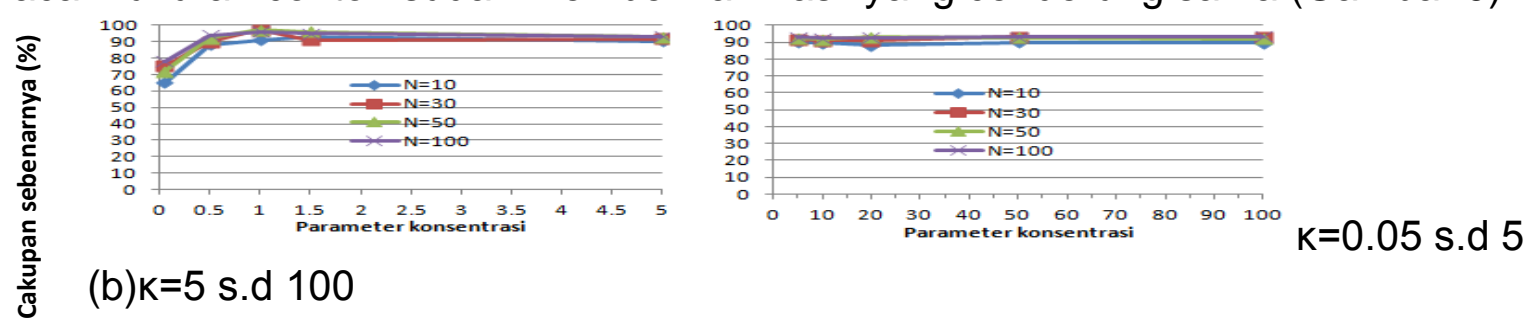

Gambar 7. Cakupan selang kepercayaan BBK Median 


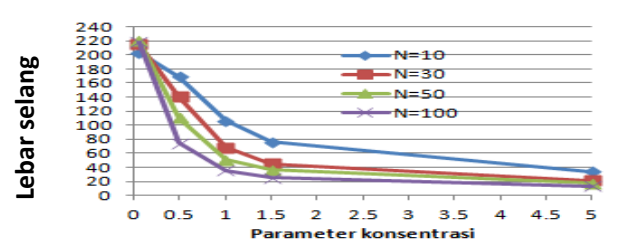

(a) $\kappa=0.05$ s.d 5

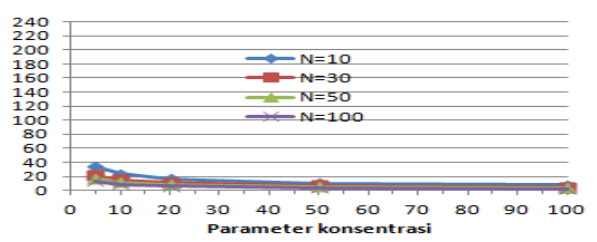

(b) $\kappa=5$ s.d 100

Gambar 8. Lebar selang kepercayaan BBK Median

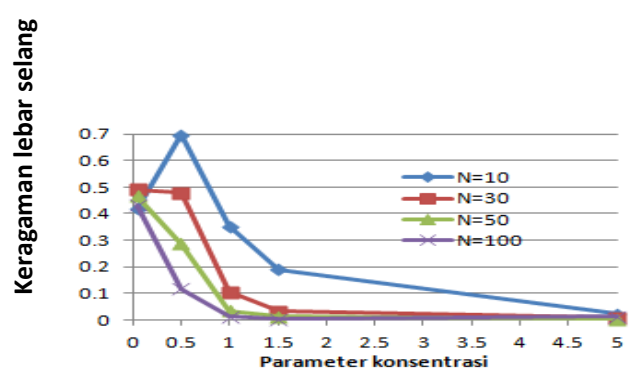

(a) $\mathrm{k}=0.05$ s.d 5

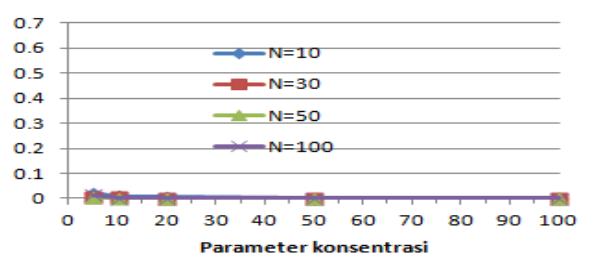

(b) $k=5$ s.d 100

Gambar 9. Keragaman lebar selang kepercayaan BBK Median

\section{d. Evaluasi Ketiga Metode}

Dari uraian hasil selang kepercayaan BES, BSIM, dan BBK, secara umum diperoleh kesamaan perilaku selang kepercayaan berdasarkan tiga ukuran. Cakupan selang kepercayaan akan terlihat stabil dan mendekati tingkat kepercayaan $95 \%$ saat parameter konsentrasinya lebih dari atau sama dengan 1 . Selang kepercayaan dari ketiga metode akan semakin sempit dan sama (konvergen) seiring dengan meningkatnya parameter konsentrasi. Hasil ini sejalan dengan penelitian Otieno (2002). Kekonvergenan lebar selang dari ketiga metode dijumpai saat parameter konsentrasinya sudah mencapai 20 . Artinya, pada data dengan $\kappa=20$ berapapun ukuran contohnya ketiga metode memberikan lebar yang relatif sama. Keragaman lebar selang memiliki pola yang sama dengan lebar selang, yaitu semakin kecil seiring meningkatnya parameter konsentrasi. Ukuran contoh kecil selalu memberikan keragaman lebar selang yang paling besar.

Parameter konsentrasi merupakan ukuran konsentrasi data terhadap arah rataratanya (Jammalamadaka\&SenGupta2001; Fisher 1995). Parameter konsentrasi yang kecil menandakan bahwa titik-titik data menyebar di sekeliling lingkaran, dan sebaliknya.Keragaman lebar selang menunjukkan konsistensi lebar selang dari 1000 simulasi.Keragaman yang besar menandakan bahwa lebar selang yang dihasilkan dari 1000 simulasi cenderung beragam atau tidak konsisten, dan sebaliknya. Hasil dugaan selang dari ketiga metode mengindikasikan bahwa, saat datanya menyebar di sekeliling lingkaran selang kepercayaan dari 1000 simulasi akan memiliki lebar yang beragam atau tidak konsisten. Saat datanya mengumpul, berapapun ukuran contohnya lebar selang dari 1000 simulasi cenderung seragam atau konsisten.

Hasil perbandingan ketiga metode menunjukkan bahwa pada $\mathrm{k}=0.05$ metode $\mathrm{BES}$ 
memiliki cakupan yang paling baik dan BSIM sama dengan BBK.Pada $\mathrm{K}=0.5$ metode BES sama dengan BSIM memiliki cakupan terbaik. Setelah $\mathrm{k} \geq 1$, cakupan selang mulai stabil dan metode BSIM yang memiliki cakupan tertinggi, metode BES tertinggi kedua, dan BBK memiliki cakupan yang paling rendah (Gambar 10).Dengan demikian, saat parameter konsentrasinya kecil maka ketiga metode memberikan cakupan yang tidak stabil.

Berdasarkan lebar selang, pada $\kappa=0.05$ metode BSIM memberikan selang tersempit dan metode BES memberikan selang terlebar. Pada parameter konsentrasi 0,5, metode BBK paling sempit dan BES paling lebar. Hal tersebut juga mengindikasikan bahwa saat parameter konsentrasinya kecil, lebar selang dari ketiga metode terlihat tidak stabil.Setelah $\mathrm{K} \geq 1$, metode $B B K$ stabil memberikan selang tersempit dan BSIM memberikan selang terlebar, sedangkan BES berada ditengahtengah (Gambar 11).

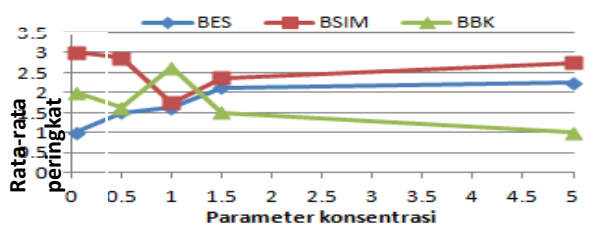

(a) $\mathrm{k}=0.05$ s.d 5

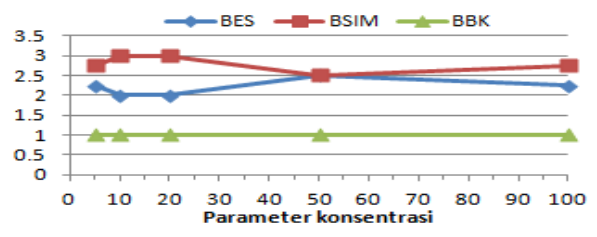

(b) $k=5$ s.d 100

Gambar 10. Rata-rata peringkat dari cakupan selang kepercayaan bagi arah median

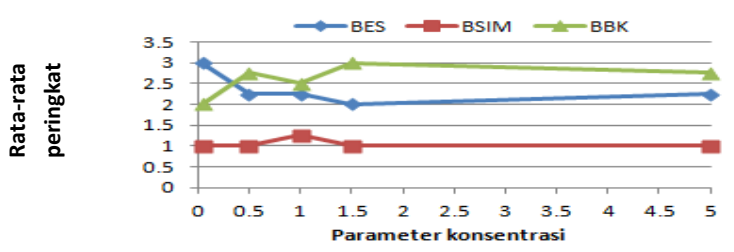

(a) $\mathrm{k}=0.05$ s.d 5

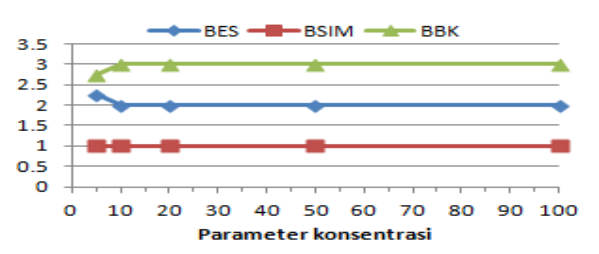

(b) $k=5$ s.d 100

Gambar 11. Rata-rata peringkat dari lebar selang kepercayaan bagi arah median

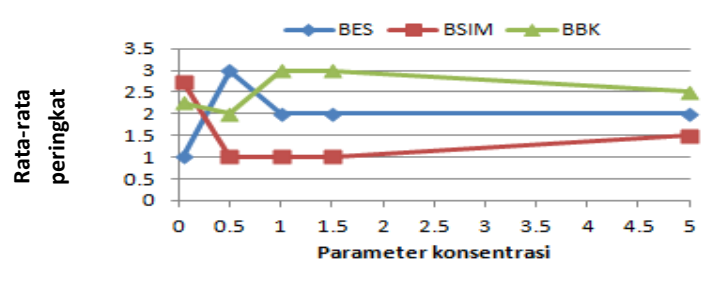

(a) $\mathrm{k}=0.05$ s.d 5

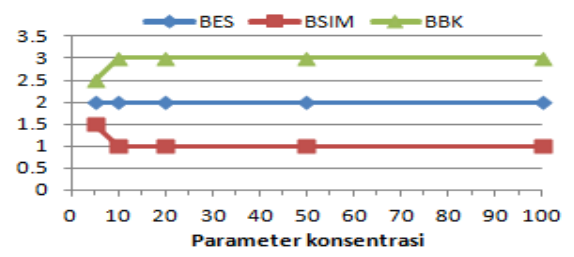

(b) $k=5$ s.d 100

Gambar 12. Peringkat dari keragaman lebar selang kepercayaan bagi arah rata-rata

Pada Gambar 12 terlihat bahwa pada saat $\mathrm{k}<1$, metode BSIM memberikan keragaman lebar selang terkecil, sedangkan BES memberikan keragaman terbesar. Namun, untukk $\geq 1$, metode BBKmemiliki keragaman terkecil, BSIMmemiliki keragaman terbesar, dan BES stabil berada di tengah-tengah.Karena metode BBK 
memberikan keragaman yang paling kecil untuk $\kappa \geq 1$, maka pada $\kappa \geq 1$ metode tersebut memiliki lebar selang lebih konsisten atau seragam dari yang lainnya.Sehingga, BBK merupakan metode yang terbaik berdasarkan lebar selang karena memiliki lebar tersempit dan keragamaan lebar selang terkecil.Metode terbaik kedua adalah BES dan terakhir adalah BSIM.

Berdasarkan perbandingan-perbandingan sesuai tiga ukuran selang, tidak ada metode yang konsisten selalu menempati peringkat tertinggi, terlebih lagi saat $\kappa<1$. Oleh karena itu, untuk $k<1$ penentuan metode terbaik tergantung pada kondisi data. Ukuran utama yang dijadikan dasar penentuan kebaikan selang adalah cakupan sebenarnya, karena ini terkait dengan keakuratan dugaan terhadap parameter populasi. Namun, untuk $\kappa \geq 1$ ketiga metode menghasilkan perbedaan angka yang tidak terlalu besar. Sehingga metode terbaik diambil dari metode yang memiliki posisi peringkat konsisten berada di tengah-tengah dari semua ukuran selang. Metode tersebut adalah busur ekor sama.

\section{Simpulan dan Saran}

Pada parameter konsentrasi yang kecil $(\kappa<1)$, ketiga metode pendugaan selang kepercayaan bootstrap bagi arah median, yaitu BES, BSIM, dan BBK menghasilkan cakupan yang cenderung tidak stabil. Setelah $\kappa \geq 1$, ketiga metode memberikan cakupan yang stabil mendekati tingkat kepercayaan. Metode yang terbaik adalah busur simetri.

Lebar selang dari ketiga metode juga tidak stabil pada pada $\kappa<1$. Pada selang parameter konsentrasi ini, metode yang terbaik adalah busur ekor sama. Pada $\kappa \geq 1$, ketiga metode memiliki lebar yang stabil dan metode yang terbaik adalah busur berbasis kemungkinan.

Secara umum, ketiga metode cenderung memberikan selang yang semakin sempit dan sama (konvergen) seiring dengan meningkatnya parameter konsentrasi. Kekonvergenan lebar selang ini dicapai saat parameter konsentrasinya sekitar 20. Dari segi cakupan dan lebar selang, metode terbaik adalah metode yang memiliki cakupan dan lebar selang konsisten yaitu metode busur ekor sama pada $\kappa \geq 1$.

\section{Daftar Pustaka}

Benton, D., \& Krishnamoorthy, K. (2002). Performance of the parametric bootstrap method in small sample interval estimates. Advances and Applications in Statistics, 2(3), 269-285.

Casella, G., \& Berger, R. L. (2002). Statistical inference (Vol. 2). Pacific Grove, CA: Duxbury.

Ducharme, G. R., Jhun, M., Romano, J. P., \& Truong, K. N. (1985). Bootstrap confidence cones for directional data. Biometrika, 72(3), 637-645.

Fisher, N. I., \& Hall, P. (1989). Bootstrap confidence regions for directional data. Journal of the American Statistical Association, 84(408), 996-1002.

Fisher, N. I. (1995). Statistical analysis of circular data. Cambridge University Press. 
Hall, P. (1988a). On symmetric bootstrap confidence intervals. Journal of the Royal Statistical Society. Series B (Methodological), 50, 35-45.

Hall, P. (1988b). Theoretical comparison of bootstrap confidence intervals. The Annals of Statistics, 16, 927-953.

Jammalamadaka, S. R., \& Sengupta, A. (2001). Topics in circular statistics (Vol. 5). World Scientific.

[Kemenkes] Pusat Data dan Surveilans Epidemiologi Kementrian Kesehatan RI. (2010). Demam berdarah dengue di Indonesia tahun 1968-2009. Buletin jendela epidemiologi, 2, 1-14.

Moore, D. S., \& McCabe, G. P. (1998). Introduction to the Practice of Statistics, Third edition. W.H. Freeman and Company

Otieno, B. S. (2002). An alternative estimate of preferred direction for circular data (Doctoral dissertation, Virginia Tech).

Rice, J. (2006). Mathematical statistics and data analysis. Nelson Education.

Suhaeni, C., Sumertajaya, I. M., \& Djuraidah, A. (2012). Pendugaan Selang Kepercayaan Bootstrap bagi Arah Rata-rata Data Sirkular. Forum Statistika dan Komputasi, 17(2), 1-8. 